\title{
When Doctors Shape Policy: The Impact of Self-Regulation on Governing Human Biotechnology ${ }^{1}$
}

\author{
Isabelle Engeli \\ Graduate School of Public and International Affairs \\ University of Ottawa \\ 55 Laurier Avenue East \\ Desmarais Building \\ Ottawa K1N6N5, Canada \\ Office phone: (+1) 613-562-5800 ext. 8804 \\ isabelle.engeli@uottawa.ca \\ Christine Rothmayr Allison (corresponding author), \\ Departement of political science \\ University of Montreal \\ C.P. 6128, succursale Centre-ville \\ Montréal, H3C 3J7 \\ Phone : 514 343-6111 \#20321 \\ Fax : 514 343-2360 \\ christine.rothmayr.allison@umontreal.ca
}

\begin{abstract}
This paper investigates the development and adoption of governance modes in the field of human biotechnology. As the field of human biotechnology is relatively new, voluntary professional self-regulation constituted the initial governing mode. In the meantime, with the exception of Ireland, all Western European countries have moved towards greater state intervention. Nevertheless they have done so in contrasting ways and the resulting governance modes for assisted reproductive technology (ART) and embryonic stem-cell research vary greatly. Instead of imposing their steering capacity in a 'top-down' fashion, governments have taken pre-existing self-regulatory arrangements in the field into account and built up governance mechanisms in conjunction with private actors and pre-existing modes of private governance. Our analysis demonstrates that the form and content of the initial self-regulation explain why the self-steering capacity of the medical profession was largely or at least partially preserved through hybrid governance systems in Britain and in Germany, while in France the self-regulation was entirely replaced by governmental intervention.
\end{abstract}

Keywords: self-regulation, human biotechnology, governance, comparative public policy, medical profession 


\section{INTRODUCTION}

This paper investigates how governance arrangements build up over time for the novel policy issue of human biotechnology. In contrast to established policy issues, at the outset, novel policy issues are largely unstructured and modes of governance are undetermined. Our analysis reveals how the continuous and contentious process of structuring a new policy problem is intimately intertwined with the establishment of governance arrangements (Capano, Rayner and Zito 2012). Studying the emergence of systems of governance for novel policy issue provides us to a certain extent with close to "laboratorylike" conditions (Migone and Howlett 2009) as all the countries studied face the same challenge of answering the question of why and how to address the risks and the uncertainties that new technological developments in human biotechnology bear.

Starting with in vitro fertilization (IVF) at the end of the 1970s, a number of major biotechnological breakthroughs have set the pace for rapid and far-reaching developments in human biotechnology. IVF has enabled the dissociation of reproduction, and opened up avenues for the development of a number of cutting-edge techniques such as genetic diagnosis and screening, cloning, and embryonic stem cell research. Advances in human biotechnology have provided effective treatment against infertility, offered great promise for the treatment of life-threatening diseases such diabetes and Parkinson's disease, and permitted the extension of organ transplants. This series of technological innovations has shed light on the field of human biotechnology as a whole, and attracted increasing public attention. While one of the IVF pioneers has recently been awarded the Nobel prize in Physiology or Medicine, serious concern has grown among the public regarding the potential health risks and ethical issues raised by the development of technologies that enable the manipulation of human embryo.

Governing human biotechnology presents states with a complex policy issue that requires balancing a series of contrasting, and potentially conflicting interests and policy goals (Weimer 2010; Salter and Frewer 2009): protection of the public, promotion of scientific and economic development. Determining how to protect society from potential medical and social abuses while encouraging technological development and stimulating the economic competitiveness by funding stem cells research constitutes one paradigmatic case of an intractable policy problem (Hisschemöller and Hoppe 1995; Schön and Rein 1995). Hence, there is no certainty on the policy means that have to be developed as well as no a priori consensus on the moral and social values that the policy should seek to pursue.

Since the early stages in the development of human biotechnology, the differences in governance modes across Western Europe intrigued and puzzled comparative public policy scholars. Given the economic and scientific potential of human biotechnology and the increased international competition in R\&D activities (National Science Board 2012 ${ }^{2}$; Ernest \& Young 2011), purely economic and interest-driven accounts of policy trajectory would predict minimal state intervention combined with strong promotional activities (Banchoff 2005: 204; Tiberghien 2009). Our case studies of France, Germany and the United Kingdom show that instead of staying out of the field, governments across Western Europe have actually taken an active part in building up governance arrangements. 
However, the resulting governance modes for assisted reproductive technology (ART) and embryonic stem-cell research vary greatly in their focus, form, aim and tools. France has fully taken over self-regulation and established traditional "command and control" governance mode. Germany has developed a hybrid mode that combines direct state regulation and self-regulation of the medical community, whereas Great Britain has mostly delegated regulatory power to an independent body. From a comparative perspective, the question arises as to how and why different modes of governance have been developed to respond to a similar intractable policy problem.

Our paper investigates how governance modes are initially developed and evolve over time into different forms of hybrid arrangements that combine direct government instruments and private governance tools. Our comparative case studies reveal that the state has progressively played a more pivotal role in the field over time. From being a external and passive observer of initial self-governance arrangements, the state has progressively become a primary player in governing the field of human biotechnology, and its responsibility and steering capacity has strengthened over time. Governments, however, instead of imposing their steering capacity in 'top-down' fashion, have taken pre-existing self-regulatory arrangements in the field into account and built up governance mechanisms in conjunction with private actors and pre-existing modes of private governance. The initial mode of regulation consisted of self-regulation developed by physicians' organizations (Rothmayr 2003, Engeli 2009; Rothmayr et al. 2004). The medical profession was directly confronted with the rapid development of the human biotechnology field and was often the first to address the concerns of their members and to issue guidelines or to adapt existing standards of conduct.

Our case studies show that the interaction of organizational factors with policyprocess specific variables explains the variation in governance arrangements. On the one hand, comprehensive and well-respected voluntary self-regulation strengthens the medical community's position as experts and its credibility as a reliable partner of the state in building up governance arrangements. On the other hand, the cohesion of policy preferences within the medical community limits the success of issue-expansion strategies of other actors with competing policy preferences, such as religious actors who have attempted to mobilize against human biotechnology and against self-governance as the predominant governance mode.

\section{Human biotechnology as an Intractable Policy Problem}

\section{The rapid pace of the development of human biotechnology}

The invention of IVF in 1978 in the United Kingdom has largely diffused worldwide and has been substantially improved since 1992 with the development of additional ART techniques increasing the success rate in cases of male infertility. Dramatically expending the range of treatments for infertility, ART techniques encountered high demand and ART medical centers have proliferated at a rapid pace. For instance, nowadays, common ART treatments lead, in the United States, to the birth of $1 \%$ of all the infants born every year and about $12 \%$ of women of childbearing age have used an infertility service ${ }^{3}$. 
While the first IVF births have been celebrated in the media as a major scientific achievement in country after country, public opinion in continental Europe soon reflected broad concern, ranging from the technological manipulation of the reproduction process to women's exposure to an excessive level of medical risk. The concerns about the social implications of biotechnology have sharply increased with the development of in vitro genetic screening in 1990 and the development of embryonic stem cell research and therapeutic cloning in subsequent years. While the scientific community has remained cautious about future treatment possibilities (see for instance Lovell-Badge 2001), the development of stem cell research and therapeutic cloning has raised hopes about future major advances for cell-based therapies to cure life-threatening diseases such as diabetes or Huntington's disease and transplant possibilities. ${ }^{4}$ There has also been increased public concern about potential scientific misuses and fears of eugenics practices that are still strongly associated among publics with the Nazi regime (Jasanoff 2005). At the same time, the biotechnology sector has been growing rapidly in the last decades (Ernst \&Young 2006), even though from late 2008 onward the financial crisis considerably slowed down R\&D investments in the sector (Ernst\&Young 2013: 23f). If reproductive and regenerative medicines have represented so far only a small share of the biotechnology sector, the therapeutic promises have resulted in increasing competition around the globe. In Asia, several governments such as India, Singapore or South Korea have targeted stem cell research as a valuable competitive niche in the biotechnology sector and have consequently invested funding (Ernst \& Young 2006, 2010) while the EU, various European countries such as the UK, and some American states, have also heavily invested in stem cell research and regenerative medicine. ${ }^{5}$

\section{The absence of international norms}

While biotechnology development and competition is a global process, so far no international norms have been established with the relative exception of the reproductive cloning ban in the European Union. In 1997 and 2005 divisions among United Nation's member states have resulted in non-binding declarations only calling upon governments to outlaw human cloning. At the beginning of the 2000s, UNESCO launched the drafting of an international convention against human cloning. While a fair number of countries, including the Bush administration, strongly supported the adoption of international norms on human biotechnology, other countries such as France, Belgium and the United Kingdom were in favor of leaving member states to decide whether cloning for research purposes should be permitted ${ }^{6}$. This split in positions let to aborting attempts to adopt regulations and the sole outcome was a non-binding declaration in 2005. Since then, the debate has not been re-opened.

At the European level, efforts toward promoting common norms regarding human biotechnology have encountered a similar fate until recently. Some major European countries such as the United Kingdom, Belgium, France and the Netherlands have not ratified the 1997 European Convention on Human Rights and Biomedicine. ${ }^{7}$ In the 2000s, similar major divergences among Member States of the European Union have prevented the elaboration of binding norms on cloning. ${ }^{8}$ It is only since the entry into force of the Lisbon Treaty in 2009 that reproductive human cloning has been prohibited through the Charter of Fundamental Rights. 


\section{Human Biotechnology as an Intractable Policy Problem}

The absence of comprehensive international norms on biotechnology has left national governments with a serious dilemma about how best to govern human biotechnology. Value-driven issues in the biotechnology sector present governments with complex policy challenges. Their multi-dimensional characteristics require balancing contrasted, and often antagonistic, interests and policy goals (Salter and Frewer 2009): protecting the public, fostering technology and promoting economic development. Determining how best responding to public concerns about the social implications of human biotechnology, while not impeding upon technological and economic development, constitutes one paradigmatic case of an intractable policy problem (Hisschemöller and Hoppe 1995; Schön and Rein 1995). Hisschemöller and Hoppe 1995 (43-45; see also Hisschemöller 1993 and Hoppe 1989) categorize four types of policy problems that vary in the degree of consensus on policy goals to be implemented and the certainty over the policy instruments to be adopted. In other terms, a policy problem is not easy or hard to solve per se. Its degree of complexity will derive from the existence and structure of the political conflict. Policy solutions on structured problems are drawn from a broad consensus over the policy aims and a shared knowledge about the means to achieve these aims. Resolving moderately structured problems is somewhat harder due to either the lack of consensual goals (ends-oriented problem resolution) or the lack of well-defined instruments (meansoriented problem resolution). Nevertheless, confidence in the broadly shared consensus over the other dimension provides governments with the means to resolve the problem. Agreement over the means, or alternatively over the ends, offers a minimal shared base on which the overall consensus may be reached through negotiation (Hisschenmoller and Hoppe 1995). Finally, unstructured problems pose a series of complex challenges for government. The high degree of conflict over both goals and means leaves government with intractable problems to solve. As the following analysis reveals, we argue that facing such a type of novel, intractable policy problem, governments have relied on the preexisting self-governance modes in the field of human biotechnology to build new, hybrid modes of governance that would provide a measure of agreement on the goals to be pursued and the means to achieve them.

\section{BUILDING UP GOVERNANCE ARRANGEMENTS ON INTRACTABLE PROBLEMS: THE INTERPLAY BETWEEN THE STATE AND PRIVATE ACTORS}

The development of alternative governance arrangements has attracted the attention of policy scholars towards self-governance modes. Policy research has shown that several alternatives to the traditional "command and control" mode exist but the question as to why and under which conditions one specific mode of governance is selected over another has remained, so far, much debated in the literature. To tackle this challenge, this paper investigates the impact of self-regulation on the choice of governance mode in the field of human biotechnology. In order to do so, we first discuss the concept of self-regulation, and then spell out the conditions under which professional self-regulation impacts the 
development of governance arrangements and formulate two hypotheses that we then test in the subsequent comparative analysis.

\section{The categorization of governance arrangements for human biotechnology}

Professional self-regulation - also called private regulation, voluntary regulation or selfgovernance - can be approached from various perspectives. In policy studies, the policy instrument perspective has been traditionally adopted to study self-regulation with the goal of determining the best type of instrument for reaching policy goals (Dryzek 1983; Ingraham 1987; Linder and Peters 1984; Ingram and Schneider 1991). In this perspective, policy instruments are conceptualized as the tools to realize the goals set out by a policy, the means that political and administrative actors use to turn their policies into action and ultimately obtain the initially defined results (Howlett 1991). Self-regulation is thereby one type of policy instrument and is best characterized by a low degree of coercion and state intervention (Howlett et al. 2009). From a governance perspective, however, selfregulation is conceived as part of a broader governance context that is "....characterized [...] by complex interdependencies and exchange relationships between public and private actors" (Knill and Lehmkuhl 2002: 49). The extent to which non-governmental stakeholders participate in deciding procedures as well as establishing and enforcing norms varies across governance modes. To explain this variation, we categorize how and to what extent governance arrangements incorporate modes of self-regulation.

Research has pointed out that simply dichotomizing government $v s$. governance or "command and control" policy instruments vs. self-regulation instruments - is not workable. Rather, recent literature emphasizes the hybrid character of governance arrangements and stresses the continuous yet changing involvement of government in systems of governance (Capano et al. 2012). Indeed, along this line, there are various forms of self-regulatory arrangements where stakeholders share decisional power to various degrees with state or other actors (Ogus 1995: 99; Gunningham and Rees 1996: 266). While the literature agrees on the fact that rule-makers and rule-takers are greatly overlapping in self-regulation - simple consultation thus does not qualify as self-regulation - there is some disagreement in the literature on the degree of overlap. For Levi-Faur (2011: 8) the key feature of self-regulation is the fact that the regulator and the regulatee are identical while in Weimer's "private rulemaking" regime (2006: 569), rule-maker and rule-taker do not have necessarily to be identical as long as authority has been explicitly delegated to stakeholders to develop and enforce regulation. In contrast, Gunningham and Rees (1997: 364) focus their definition on non-delegated forms of self-regulation: “...the normative orders of private governments (such as corporations, schools, hospitals), and the normative orders of professional communities and business networks".

Given the strong self-regulatory tradition of the medical profession, we argue that self-regulation does not result only from explicit delegation. Physician's self-regulation results from a long-term interaction between private and public actors and should not be taken as a spontaneous process detached from the state (Hassenteufel 1997). It is nevertheless this strong self-regulatory tradition that allows, in return, the medical profession to address any new emerging medical issues without explicit delegation from the state. Furthermore, self-regulation can also be the dominant mode of governance in 
situations where political actors fail to adopt policies, i.e. because of fundamental value conflicts threatening governmental coalitions or potential electoral costs. In order to be able to analyze governance modes in the field of human biotechnology, our analysis therefore focuses on formalized forms of self-regulation - where actors have agreed upon specific norms or rules in an explicit way and follow some type of recognized procedure but is not limited to the explicit delegation mode of self-regulation and includes selfregulation without the intervention of the state.

We define self-governance as the governance mode where the targeted stakeholders decide over the norms or the mechanisms of decision-making and implementation, or share this power with state actors or other actors within the policy network of actors. Such power can be explicitly delegated or not, but in both cases rulemaking is based on some type of recognized procedure in order to adopt formal rules. Such self-governance mode might also vary in terms of their reach, their "monopolistic power" (Ogus 1995: 100). In cases where self-regulatory norms are only adopted by some, but not all relevant stakeholders, there is the possibility of competing self-governance modes. National medical associations might be composed of various regional associations, and there are also specialized medical organizations. In addition, given the growing importance of the reproduction industry, there are standards or guidelines of practice at the clinical level, e.g. adopted by a specific group of reproductive clinics. Therefore, when investigating governance modes, we need to take into account the possibility of multiple self-governance arrangements that might influence policy-making processes. Accordingly, we categorize governance modes in terms of how strongly stakeholders are involved in rule-making into four different types that constitute a continuum.

Voluntary self-regulation is characterized by full control over rule-making by the stakeholders without that power being explicitly delegated to them. As the human biotechnology field is relatively new, such voluntary self-regulation constituted what we call the initial governance mode, and preceded any state intervention (Engeli and Rothmayr 2012).

Next we distinguish delegated self-regulation, where stakeholders also enjoy full control over rule-making, but where power has been expressly delegated to them. In delegated self-regulation mode, the substance of policy-making is delegated through a formal decision in form of a law, regulation etc. The power to self-regulate is thus recognized by the state and the stakeholders cannot choose whether to self-regulate but are obligated to do so. In contrast to voluntary self-regulation, the issue to be regulated has accessed the political agenda and resulted in the decision to delegate.

In the case of partial delegated self-regulation, rule-making is shared between the state and stakeholders and the latter have only partial control over the substance of the regulations. This type of governance mode might take various forms. For example, while stakeholders may develop the norms to be applied, these norms or rules might have to be approved through another body, by the state bureaucracy or by an independent body (see Levi-Faur 2011). Alternatively, the state might specify in detail the procedures structuring the process of self-regulation, and impose certain conditions on how, when etc. the norms and rules have to be adopted. A third form of partial delegated self-regulation might consist of the state adopting regulations for certain issues, and leaving the regulation of others explicitly to stakeholders. 
From these three forms of self-governance modes, we distinguish "command and control" mode - the traditional mode of government. In such a mode, stakeholders might be consulted or deploy various lobbying efforts, but they are not substantively involved in rule-making processes through delegation. The stakeholder's expertise is mobilized through consultation, yet without sharing decisional power (see Weimer 2006).

Western European countries have all moved from the initial mode of voluntary self-governance toward more state intervention into the regulation of the field, with the exception of Ireland. Our paper investigates how governance modes are initially developed and evolve over time into different forms of hybrid arrangements that mix direct government instruments and private governance tools. We argue that governments, instead of imposing their steering capacity in a 'top-down' fashion, have taken preexisting self-regulatory arrangements in the field into account and built up governance mechanisms in conjunction with private actors and pre-existing modes of private governance.

The literature has addressed the phenomenon of combining private and public governance modes under the term of policy mix, instrument mix and also hybrid systems or organizations of service delivery mainly in the fields of environmental, regulatory and welfare policies (Howlett and Rayner 2007; Evers 2005; van der Heijden 2011). Following van der Heijden (2011), a hybrid aims at "combining the strengths of both sectors", private and public, and are defined by the fact that "both public and private sector agencies operate in the same field" (van der Heijden 2011: 368). Such hybrid systems vary according to the importance of private and public sector involvement (van der Heijden 2011: 370). In line with Evers (2005), we prefer, in this article, the term of hybrid governance to policy mix, because the concept of hybrid points to the fact that we are not simply looking at combinations of two types of policy instruments, but that we are interested in the emergence of "institutions that are shaped simultaneously by all three possible sectors, their values, and their steering mechanisms ", i.e. the market (private clinics), civil society (medical associations, interest groups) and the state (Evers 2005: 738).

\section{The impact of self-governance on choice for governance mode}

Stakeholders often play an important role in policy-making processes because of their expertise, but also because they are indispensible partners for successful policyimplementation. Their governance capacity, in terms of organizational structures and abilities, is hereby an important factor for explaining what form hybrid modes of governance might take, i.e. for explaining the importance self-governance mechanism within a specific governance arrangement (Knill and Lehmkuhl 2002).

We assume that medical associations want to preserve as much freedom for practicing human biotechnology as possible. This does not necessarily mean that they want no state intervention at all. The clarification of some legal parameters - for example pertaining to civil law issues (such as filiation) - are outside of their self-regulatory capacity, but are essential for the well functioning of the human biotechnology industry. Yet, previous research points out that medical associations want to preserve their autonomy in terms of medical practice, and this independently from their substantive 
preferences for what to practice and how to practice human biotechnology (Rothmayr 2003, Engeli 2009, Bleiklie et al. 2004). Given their strong self-regulatory tradition, but also their interest in preserving self-regulation, one strategy is to adopt voluntary selfregulation early in the policy-making process. As pointed out above, we assume that such initial voluntary self-regulation might have an impact on subsequent policy-making processes. As we argue next, institutional characteristics of voluntary self-regulation for human biotechnology, namely their comprehensiveness and enforcement mechanisms, vary across countries. The variation in governance capacity (Knill and Lehmkuhl 2002) might help us to better understand why self-regulation influences policy-making processes and the resulting systems of governance in some cases, but not in others. We thereby understand governance capacity not simply as an organizational attribute (Knill and Lehmkuhl 2002). In the case of the novel, and intractable policy issue of human biotechnology, to what extent medical actors succeed in influencing how the problem is structured and framed, constitutes a crucial factor for explaining the impact of selfgovernance on the governance mode.

Within policy studies, cognitive approaches assume that actors make sense of the world and policy questions by reducing complexity and focusing on certain aspects of a problem, while leaving others on the side. Voluntary self-regulation impacts the framing of human biotechnology. It reduces 'problem pressure' and influences the agenda-setting process. Voluntary self-regulation frames human biotechnology as primarily a medical issue instead of a moral problem. Through self-regulatory mechanisms, the medical profession shows the public that it is capable and willing to address the most urgent issues. Private actors demonstrate that they dispose of sufficient 'governance capacity' (Knill and Lehmkuhl 2002: 48) which depends on the "...extent to which organisations are able to influence, monitor, and sanction the behavior of their members...". Governance capacity finds its expression not just in terms of enforcement capability, but also in terms of policyformulation, i.e. to strike standards or policies that address not just marginal issues related to human biotechnology, but address the major questions in a fairly comprehensive way. The demonstration of governance capacity strengthens the position of medical actors in the policy-making process in two ways. First of all, in contrast to other state or private actors, they dispose of concrete expertise and knowledge in regulating the issue. Second, they demonstrate their policy-making and enforcement capabilities and hence contribute to a favorable evaluation of their enforcement activities. This is of particular importance, as professional expertise has come under increasingly critical scrutiny over the last decades. Successful voluntary self-regulation strengthens their position as experts and their credibility as reliable partners in the regulatory process. Our first hypothesis, hence, postulates, that comprehensive and well-respected voluntary self-regulation of human biotechnology increases the likelihood of partial or fully delegated self-regulation.

The second factor that we expect to have an important impact on regulatory courses and the development of governance mode pertains to the preferences of the medical profession itself. Research on biotechnology has shown that substantive preferences of medical associations do vary across countries (Rothmayr 2003, Engeli 2009, Bleiklie et al. 2004). In some cases, medical associations opted for very stringent self-regulations, limiting what doctors could offer in terms of services, for example surrogacy or embryo donation; in other cases their self-regulation was fairly liberal aiming 
at quality assurance. Furthermore, we cannot assume that the medical profession's preference is for no state intervention at all. Human biotechnology raises a number of questions that might best be regulated by law (for example in terms of defining who the parents are in cases of gamete or embryo donation) and which go beyond the medical profession's self-regulatory capacity. While we can assume that the medical associations want to preserve as much freedom to practice assisted reproduction as possible, they might at the same time welcome state regulations that facilitate the functioning of the assisted reproductive industry by clarifying a number of legal parameters. Furthermore, the medical profession is not necessarily a homogenous group and preferences for how far and how deeply the state should intervene in regulating human biotechnology varies not only across countries but also within the membership of individual associations. Dissent over the extent to which state should intervene in the field and over the degree of regulatory permissiveness may occur within the medical community. Such dissent weakens the lobbying capacity of the professional organizations and compromises its capacity to impact on policy choices (Knill and Lehmkuhl 2002: 48). This is particularly the case for the field of human biotechnology, which involves the manipulation of human embryo. Cohesion in policy preferences within the medical community allows for controlling how the issue is framed and preventing any kind of issue expansion (Schattschneider 1975; Elder and Cobb 1972, 1983).

The medical community is not the sole actor interested in the issue of human biotechnology and in order to understand the impact of self-regulation we need to analyze it within the context of the overall structure of the political conflict surrounding assisted reproduction. In a similar vein than the conflict over abortion liberalization, the manipulation of human embryo triggers the mobilization of religious actors. Religious groups together with religion-based political parties such as Christian Democrats will likely seek to that protect "the beginning of life" and therefore advocate restrictive policies or perhaps even total bans through strong forms of state intervention eliminating all selfregulatory mechanism or limiting them severely to minor issues of medical practice (Engeli et al. 2012b). Religious actors were clearly the 'losers' of the initial mode of selfregulation entirely left to the professional organizations. Through the strategy of issue expansion, religious actors aimed at reframing the issue at stake and challenge the initial policy monopoly of the medical community (Baumgartner and Jones 2009: 53ff).

We argue that cohesion of policy preferences within the medical community greatly contributes to their capacity to influence the choice of governance mode for human biotechnology. Speaking with one voice may counter the mobilization of religious actors and prevent issue expansion. Indeed, preserving the framing of human biotechnology as being a primarily health-related question maintains the medical community as the principal legitimate stakeholder. In contrast, fragmentation over policy preferences within the medical community provides other actors with the opportunity to challenge this dominant frame and successfully associate human biotechnology with more general issues, such as the abortion conflict (Banchoff 2005; Engeli et al. 2012b) or the negative impact of scientific advances on society. Expanding the scope of conflict attracts public attention towards how best to govern the field and breaks down the policy monopoly of the medical community. In doing so, religious actors may succeed in mobilizing a broader array of interests and thus render it more difficult for a fragmented medical community to control 
problem definition and, accordingly, regulatory policy-making. Our second hypothesis, therefore, reads as follows: If there is no consensus over the preferences regarding the desirable degree of state intervention within the medical community, systems of governance with no or very limited self-governance mechanisms are more likely to be developed.

Drawing on comparative case studies of France, Germany and the UK, our analysis shows that comprehensive and well-respected voluntary self-regulation strengthens the medical community's position as expert and its credibility as reliable partners in the regulatory process. In addition, the cohesion of policy preferences within the medical community prevents the issue-expansion strategy of other actors with competing policy preferences, such as religious actors who mobilize against human biotechnology and selfregulation.

\section{FRANCE: TAKING OVER A SELF-REGULATORY MESS}

The French governance mode for human biotechnology is a classic form of "command and control". During the 1980s, some voluntary self-regulation within the medical community was first developed to address medical and ethical issues related to sperm and egg donation and was then extended to cover ART techniques themselves. The initial state regulation in 1988 only imposed licensing procedures upon assisted reproductive technologies medical centers and left the regulation of the field to the medical community. Nevertheless, the self-regulatory guidelines were not respected by the whole community and an important split emerged among physicians. In addition to the long-standing institutional fragmentation of the medical community, divided opinions on how best to regulate the field pushed the government to take over its regulation and develop a comprehensive legislative framework on human biotechnology.

The medical community has been very active in the public debate on human biotechnology since the diffusion of in vitro fertilization in the early 1980s in France, but it failed to speak with a unified voice. The two main professional organizations - the National Order of Physicians and the National Academy of Medicine - were very reluctant to launch any self-regulatory process on human biotechnology. It were the largest assisted reproductive technologies (ART) centers at that time which grouped together into several federations and developed comprehensive guidelines to regulate specific aspects of ART at first - such as sperm donation firs and then later ART techniques more comprehensively. ${ }^{9}$ Notably, the centers specialized in sperm and later egg donation were the first ones to form a federation, the CECOS. If the federations grew rapidly and their guidelines were well respected among their respective members, the public craze for ART in France resulted into a rapid increase in ART centers and they did not all follow the various guidelines. The initial regulation in 1988 introduced a licensing procedure that failed to monitor the supply of ART treatment. As a result, ART practices increasingly diverged and the field was divided between the different federations and their competitors, which opened up ART practice to surrogacy, single motherhood, and the use of a deceased husband's sperm. Divergence in ART practices expanded the public controversy on ART more generally and took it out of just the medical community; the situation was criticized for promoting confusion. ${ }^{10}$ This chaotic scenario pushed the government to resume its 
efforts to substantively take control of the field of human biotechnology. After a long process of public consultation and decision-making, the resulting 1994 laws on bioethics comprehensively regulated the field and severely constrained ART practices. The human embryonic stem cell research breakthrough led the government to revise the laws on bioethics and impose a restrictive "command and control" regulation on embryo-related research in 2004 and 2011. ${ }^{11}$

The impact of voluntary self-regulation on the governance arrangements developed in France is relatively weak. On one hand, the CECOS succeeded in imposing its regulatory rules on sperm, egg and embryo donation that were almost fully integrated into the successive laws, and it did so against the policy preferences of its main medical competitors. On the other hand, the French state's takeover of the regulation of the field severely constrained technological development in the area of human biotechnology, in particular regarding embryonic stem cell research. The medical community, including the CECOS, pleaded in vain for more room for maneuver and greater self-regulation. The institutional fragmentation of the medical community, the lack of leadership from the main professional organization, together with the competition among the ART practitioners and the great differences in policy preferences within the medical community explain to a great deal the comprehensive intervention of the French state into the field of human biotechnology. The representation of health care professionals has been traditionally fragmented in France and has negatively impacted the relationship between health actors and the State in several ways (Hassenteufel 1997). Neither the National Academy of Medicine nor the National Order of Physicians demonstrated any will to take the leadership in establishing voluntary self-regulation that would have exerted a biding effect on ART practices. In addition, the National Order of Physicians has been challenged by a substantial part of the profession since its creation by the Vichy regime. One of the peaks in this struggle occurred during the 1970s with development of alternative medicine. Among others, the abortion issue crystallized this growing fractiousness (Engeli 2011). While the National Order was strongly opposing the liberalization of abortion, some young doctors were openly practicing abortion and publicized their opposition to the NOP. Three of the ART pioneers in France were among them and they were later co-founders of CECOS. Nonetheless, the reluctance of the national organizations to address the issue of ART did not prevent the development of self-regulation. Some of sperm donation centers were the first ones to create a federation to protect their interests in 1981. Later in the 1980s, they were followed by public and private IVF centers, as well as ART laboratories. All these organizations developed some rules of conduct, best practices, and reporting procedures that were well-respected among their respective members. These various attempts at self-regulation were never fully coordinated and the different organizations never merged together to speak with one voice. Moreover, the fragmentation of the representation of health actors was worsened by the spread of competing ART centers that did not respect these self-regulatory rules. The competing centers also expressed divergent policy preferences and promoted alternative ART techniques such as surrogacy and postmortem sperm donation, which sparked heated controversy in France. The CECOS was calling for state intervention into the regulation of the field while other ART actors were opposing any form of public intervention into what they considered being an arena of private choice. 
Weakened by its deep fragmentation in terms of representation and policy preferences, the medical community failed to prevent the expansion of the scope of conflict. The public debate on ART saw the emergence of non-medical actors - such as religious organizations and women's groups- who promoted an alternative framing of the ART issue; they questioned the legitimacy of "science for science's sake" and the social and moral implications of ART development. The debate was such that the government launched a large scale exercise in deliberative democracy in the early 1990s, seeking to engage the public on how best to govern the field, which was highly unusual in the French unitary system of government (Meny 2008). The consultation procedure was employed again for the revised laws on bioethics in 2004 and 2011. During the consultation and the legislative processes over the 1990s and 2000s, the medical actors were represented but were only one set of actors among many, and with no privileged place in the process.

The French case clearly demonstrates how divided policy preferences and the lack of comprehensive self-regulation have an impact on the development of the system of governance over time. The French government was initially reluctant to intervene in the field of human biotechnology. It was nevertheless facing increasing public pressure to intervene. Without any consensus among the medical community to rely on, it took over regulation entirely. The resulting "command and control" regulatory solution was intended to ease public concern about ART, on the one hand, but it was also adopted to substitute for the lack of binding self-regulation, on the other hand.

\section{THE UNITED KINGDOM: THE INCREASING POWER DELEGATION OVER TIME}

The governance arrangements for assisted reproduction and embryo-related research in the United Kingdom are the most advanced form of delegated self-regulation in the field of human biotechnology across Western Europe. The UK system of governance still contains some "command and control" features - a number of explicit prohibitions are stated in the parliamentary acts governing the field. The delegation of regulatory authority has nevertheless constituted a key element of the regime since its initial stage in the early 1990s and it has been further expanded over time. The UK case shows how a rapid and well-respected voluntary self-regulation together with shared policy preferences among health professionals allows to contain the ART issue within a medical and science frame, which in turn greatly impacts the evolution of the governance arrangements over time.

The UK has been a leading country in the field of human biotechnology since the early stage with the world's first successful IVF in 1978. The first test-tube baby attracted a great amount of attention. Public enthusiasm was nevertheless mitigated with concern regarding the consequences of this breakthrough and future technological developments. The government quickly considered the ART issue to be a 'politically hot potato' and mandated a Committee of Inquiry in 1982 to make review the social and ethical implications of technological development in the field of human biotechnology and advice the government on how best to regulate field (Blank 2004: 123). The Warnock Committee's permissive recommendations drew some strong opposition, notably moral objections regarding the absence of any embryo legal status. Under the joint leadership of the main professional organizations - the Royal College of Obstetricians and Gynecologists and the Medical Research Council, the medical community followed the 
Warnock Committee's recommendations and quickly set up a voluntary licensing authority. Under Major first government, this voluntary licensing authority was then adopted in the 1990s Human Fertilization and Embryology Act and became the Human Fertilization and Embryology Authority (HFEA). While the 1990 Act established a limited number of prohibitions, such as the implantation of animal embryo in women, it is best characterized by its wide delegation of regulatory power to the HFEA. Indeed, the HFEA was granted a broad regulatory autonomy deciding how ART and embryo research was to be conducted. In addition to its rule enforcement function, the HFEA has also been delegated rule-making power: HFEA has full authority not only to license and monitor ART and embryo research but also to regulate practices through its Code of Practice, which set binding requirements as well as guidance for ART practices and embryo research. Moreover, the legal framework does not impose much of prescription or prohibition regarding which ART techniques have to be allowed and what embryo research has to be conducted. Through its licensing capacity, the HFEA actually de facto decides the direction of ART and research development, as long as the licensing applications comply with the parliamentary Acts. This power delegation power has been strengthened over time with the 2001 and 2008 revision of the 1990 Act and the 2001 Human Reproductive Cloning Act.

While the medical community did not precede the government in developing any form of voluntary self-regulation, they had quickly showed their willingness in collaborating with the government to develop governance arrangements from its initial stage. Indeed, the majority of the Warnock Committee members were science and health actors and the medical and research community is still nowadays well-represented within the HFEA board. The medical community did not stop at successfully establishing its institutional representation. Concerned with potential contestation of the legitimacy to interfere into the reproduction process (McLaren 2002), the professional organizations did not wait for the passing of any parliamentary Act to establish a voluntary licensing authority in charge of reviewing, authorizing and inspecting ART and research activities in 1985 (Allan 2010). ${ }^{12}$ The form and scope of this voluntary self-regulatory body closely followed the recommendations of the Warnock report. While no sanction was include in case of non-compliance, most of the ART and research centers applied for a license and respected the guidelines (McLaren 2002; Blank 2004). The development of this voluntary authority exerted an important impact on the development and evolution of the UK system of governance over time. It demonstrated both the efficacy and efficiency of such authority. It provided the government with some evidence of the success of licensingbased regulatory approach that facilitates science advance while allowing little but key scientific gate keeping in the "command and control" features of the governance arrangements. As a result, the key features of the HFEA are very similar to the voluntary authority ones, and its power authority has been increased over time.

The broad consensus over how best to regulate the field among the medical community did provide the professional organizations with an opportunity to open up the actors' network without risking any issue expansion. To strengthen the transparency of the voluntary self-regulation mechanism, the professional organizations opened up this regulatory body to lay people. If the first test-tube baby attracted a great amount of attention, public enthusiasm was nevertheless mitigated with concern regarding the 
consequences of this breakthrough and future technological developments. Here as well, the professional organizations closely followed the Warnock recommendations and took care to counter-balance the over-representation of the medical and research community. The self-regulation impacted on the shift in public opinion regarding the ART issue. At the time when the 1990 Act was passed, public support for ART and embryo research took over the skepticism and fears of the early 1980s. As a member of the Warnock committee puts it (McLaren 2002: p. 427), the voluntary self-regulation provided "(...) very valuable reassurance to the public that there weren't nasty scientists doing witched things behind closed doors". The social and political legitimacy of self-regulatory mechanism in the UK was confirmed with the 2001 revision of the 1990 Act which allows for embryonic stem cell research and the creation of embryos for research purpose.

\section{GERMANY: COMBINING EMBRYO-PROTECTION WITH SELF-REGULATION}

The system of governance for assisted reproduction in Germany combines self-regulatory governance with federal legislation, and can be interpreted as a governance mode with partial delegation (Rothmayr and Ramjoué 2004, Abels and Rothmayr 2007, and Rothmayr 2006). As our analysis shows, the Bundesärtzekammer, the German Medical Association, has a strong tradition and institutionally recognized capacity of selfregulation. In a political context, where assisted reproduction is highly politicized because of the abortion debates in the past and the experience of World War II, their selfregulatory capacity is crucial to understand the resulting governance arrangements.

Since the 1980s the German Medical Association has been very present in the public debate on assisted reproduction and the discussions among its members. Since 1985 the professional code (Berufsordnung) of the German Medical Association regulates assisted reproduction in Germany (Bundesärtzekammer 1985, 1988, 1998, 2006). The German Medical Association elaborates a model professional code (MusterBerufsordnung) which is then adopted by the Länder Medical Chambers. The professional code is binding law on the Länder level and can be enforced in court. Their self-regulation preceded federal legislation. The Embryo Protection Act (Embryonenschutzgesetz), adopted in 1990 under a coalition government of Christian-Democrats (CDU/CSU) and Liberals (FDP), focuses on protecting the embryo from possible harm by the new technology. In 2002 and then in 2011 two important legislative changes occurred: first, under a Social-Democratic government, the Bundestag decided to allow for the research on imported stem cell lines (Stammzellgesetz, StZG), and second, under coalition government of Christian-Democrats (CDU/CSU) and Liberals (FDP) to allow for preimplantation genetic diagnostics on a case to case basis (Präimplantationsdiagnostikgesetz

- PräimpG $)^{13}$. Around all three decisions, there was strong mobilization and a broad public debate, and accordingly, the medical association was just one voice among others.

The German legislation strongly focuses on embryo protection and, in contrast to other countries, does not propose a comprehensive legislation on all aspects of assisted reproduction. The framing of assisted reproduction in terms of embryo protection is the result of several components: In 1975 the Federal Constitutional Court declared the abortion law to be unconstitutional and stated that the constitutional protection of human dignity (Art. $1 \mathrm{GG}$ ) and the right to life (Recht auf Leben, Art. 2 GG) apply to the embryo 
after implantation and the State accordingly recognized the obligation to protect the embryo. This jurisprudence on the protection of the embryo strongly contributed to framing ART in terms of embryo protection. Evidently, the fact that the ChristianDemocrats were in power, and the broad mobilization of religious interest groups and the Churches (Landeskirchen) are crucial in order to understand this very specific focus of the debate. However, the comprehensiveness of their early voluntary self-regulation and their strong enforcement capacity due to the legally binding character of the professional code equally contribute to explaining the absence of a more comprehensive federal legislation for assisted reproduction.

Through the fact that the Länder Medical Chambers are public law bodies and the professional code is legally binding, medical self-governance is explicitly delegated to the medical community and what constitutes on the first glance voluntary self-regulation has a binding legal status. From the beginning of the agenda-setting process, the German Medical Association proofed to be a reliable partner, setting national, well respected standards for a broad range of assisted reproductive technologies and related ethical issues. The professional code imposed limits, guided doctors in their therapeutic choices, assured patients of quality and guaranteed them the necessary counseling. Even if the medical profession would have preferred a more comprehensive legislation, there was already a functioning self-regulatory regime in place anchored in the strong German neo-corporatist tradition. The self-governance is certainly not the cause of the focus on embryo-protection, but it reduced the scope of conflict, and rendered a multi-faceted, very divisive issue tractable: why bother about additional, potentially equally divisive issues, if the medical profession proofed willing and capable of finding a consensus, adopt meaningful guidelines and enforced them? ${ }^{14}$

It has now been 22 years since the Embryo protection law has been adopted, and there would have been ample time to adopt a more comprehensive legislation, but this has not happened. Additional legislation on stem-cell research and pre-implantation diagnostics have been adopted in order to take into account more recent developments. As the stem-cell research and the preimplantation genetic diagnostics debate revealed, putting assisted reproduction on the agenda is very costly in Germany and divides political parties internally, to the extent that in both cases there was a free vote in the Bundestag where MPs had not to follow a party line in order to render the intractable problem governable and assure the strong presence of the state in regulating human biotechnology. Nevertheless, while the state strongly intervenes, he continues to rely on self-governance mechanism for various issues that in other countries, such as France, Switzerland, Austria or Italy are solely regulated through governmental legislation.

\section{CONCLUSION}

The comparative case studies of the development and evolution of the system of governance for human biotechnology in France, the UK and Germany has revealed that the state has progressively played a more pivotal role in the field over time. From being an external and passive observer of initial self-governance arrangements, the state has progressively become a primary player in governing the human biotechnology field and its responsibility and steering capacity has strengthened over time. In the three countries, 
government has become a pivotal actor in developing governance arrangements over time and is key to any of the hybrid governance arrangements that have been articulated to govern human biotechnology. In this respect, the three cases follow the general pattern of stronger state intervention over time that we can observe in Western-Europe, which meant in some cases overcoming initial limits to the state's capacity of coordinating political and societal actors (Knill and Lehmkuhl 2002) for a novel, highly divisive issue.

If government's primary role in governing the field is a constant in our case studies, the contrast between the systems of governance that have been developed points out that the way in which government exerts its steering role is in turn mediated by selfgovernance mechanisms established by private actors. Professional self-regulation matters in the development of governance modes for intractable policy problems such as human biotechnology. In fact, medical associations mobilized their prior general -- not human biotechnology specific -- self-regulatory capacity with various degrees of success. Comprehensive and well-respected voluntary self-regulation strengthens the medical community's position as expert and its credibility as a reliable partner in the regulatory process. As the UK case demonstrates, the mobilization of the medical community under the leadership of the main professional organizations provided the government with strong evidence of the efficacy and efficiency of self-regulatory mechanisms. In addition, the broad policy consensus within the medical community allowed for opening up the policy network without risking any issue expansion. The professional organizations took great care to integrate lay people into self-regulatory bodies and provided the general public with high levels of information on technological development and possibilities for future treatments. On the contrary, faced with severe public concern about the implications of human biotechnology development, the French government was left with a chaotic selfregulatory situation and competing ART stakeholders. The UK government could rely on professional self-regulation while the French government took over the regulation of the field entirely. The German case presents some mixed evidence. The professional community was well-organized and developed comprehensive self-regulation. They failed, however, to impose a fully delegated regulatory regime and had to contend with strong opposition, notably from religious actors. Professional self-regulation nevertheless prevented a total ban on ART that was promoted by the latter. It has reduced the scope of the controversy and contributed to reaching a policy compromise, despite the high level of political conflict over how best to regulate the human biotechnology field.

In short, the comparison of the three cases reveals that the ability of private actors to influence governance modes depends only partly on their organizational capacity in the strict sense. Rather whether and to what extent they succeed in influencing how a novel problem is structured and framed turns out to be crucial. Nevertheless, their success in shaping a novel problem through self-regulatory processes and hence successfully limiting issue expansion also depends - as the case studies demonstrate - on the mobilization of other actors. 


\section{REFERENCES}

Abels G, Rothmayr C (2007) ART and GMO Policies in Germany: Effects of Mobilization, Issue-Coupling, and Europeanization. In: Montpetit E, Rothmayr C, Varone F (eds) The Politics of Biotechnolgoy in North America and Europe, pp. 145-168. Lexington Books, Lanham.

Banchoff T (2005) Path Dependence and Value-driven Issues. The Comparative Politics of Stem Cell Research. World Politics 57, 200-230.

Baumgartner F, Jones B (2009) Agendas and Instability in American Politics. University of Chicago Press, Chicago

Bleiklie I, Goggin ML, Rothmayr C (2004) Comparative Biomedical Policy. Routledge, London.

Blank RH (2004) The United Kingdom: regulation through a national licensing authority. In: Bleiklie I, Goggin ML, Rothmayr C (eds) Comparative Biomedical Policy: Governing assisted reproductive technologies, pp. 120-137. Routledge, London.

Bundesärtzekammer (2006) (Muster-)Richtlinie zur Durchführung der assistierten Reproduktion (Novelle 2006).

Bundesärtzekammer (2011) Memorandum zur Präimplantationsdiagnostik (PID) Dtsch Arztebl 108: A-1701 / B-1449 / C-1445.

Capano G, Rayner J, Zito A (2012) Governance from the Bottom Up: Complexity and Divergence in Comparative Perspective. Public Administration 90, 56-73.

Elder CD, Cobb RW (1972) Participation in American Politics: The Dynamics of AgendaBuilding.

Druckman JN (2001) On the Limits of Framing Effects: Who Can Frame. The Journal of Politics 63, 1041-1066.

Dryzek JS (1983) Don't Toss Coins in Garbage Cans: A Prologue to Policy Design. Journal of Public Policy 3, 245-368.

Engeli I (2009) The Challenges of Abortion and Assisted Reproductive Technologies Policies in Europe. Comparative European Politics 7(1): 56-74.

Engeli I, Green-Pedersen C, Larsen LT (2012) Morality Politics in Western Europe. Parties, Agenda and Policy Choices. Palgrave, London

Engeli I (2012) Policy Struggle on Reproduction: Doctors, Women, and Christians. Political Research Quarterly 65, 330-345.

Engeli I, Rothmayr Allison C (2013) Diverging against All Odds? Regulatory Paths in Embryonic Stem Cell Research across Western Europe. Journal of European Public Policy 20, 407-424.

Ernst \& Young (2011) Beyond Borders: Global Biotechnology Report 2011, available at http://www.ey.com/GL/en/Industries/Life-Sciences/Beyond-bordersglobalbiotechnology-report-2011, accessed: 20 July 2012. 
Ernst\&Young (2013) Beyond Borders: Matters of Evidence. Biotechnology Industry Report 2013, available at http://www.ey.com/Publication/vwLUAssets/Beyond borders/\$FILE/Beyond borders. pdf, accessed 17 mai 2013.

Evers A (2005) Mixed Welfare Systems and Hybrid Organizations: Changes in the Governance and Provision of Social Services. International Journal of Public Administration 28, 737-748.

Gunningham N, Rees J (1997) Industry Self-Regulation: An Institutional Perspective. Law \& Policy 19, 363-414.

Hajer MA (2009) Authoritative Governance: Policy-making in the Age of Mediatization. Oxford University Press, Oxford

Hassenteufel P (1997) Les médecins face à l'Etat. Une comparaison européenne. Press de sciences po., Paris

Hisschemöller M, Hoppe R (1995) Coping with intractable controversies: The case for problem structuring in policy design and analysis. Knowledge and Policy 8, 40-60.

Howlett M, Rayner J (2007) Design Principles for Policy Mixes: Cohesion and Coherence in "New Governance Arrangements". Policy and Society 26, 1-18.

Howlett M, Ramesh M, Perl A (2009) Studying Public Policy: Policy Cycles \& Subsystems. Oxford University Press, Don Mills.

Howlett M (1991) Policy Instruments, Policy Styles and Policy Implementation: National Approaches to Theories of Instrument Choice. Policy Studies Journal 19, 1-21.

Ingraham P (1987) Toward More Systematic Consideration of Policy Design. Policy Studies Journal 15, 611-628.

Ingram H, Schneider A (1991) The Choice of Target Populations. Administration \& Society 23, 333-356.

Jasanoff S (2005) Designs on Nature: Science and Democracy in Europe and the United States. Princeton University Press, Princeton

Knill C, Lehmkuhl D (2002) Private Actors and the State: Internationalization and Changing Patterns of Governance. Governance: An interntional Journal of Policy, Administration, and Institutions 15, 41-63.

Levi-Faur D (2011) The Handbook on the Politics of Regulation. Edward Elgar Publishing, Cheltenham

Levi-Faur D (2011) Regulation and Regulatory Governance. In: Levi-Faur D (ed) The Handbook on the Politics of Regulation, pp. 1-20. Edwar Elgar Publishing, Cheltenham

Linder S, Peters GB (1984) From Social Theory to Policy Design. Journal of Public Policy 4, 237-259.

Majone G (1994) The Rise of the Regulatory State in Europe West European Politics 17, 78-102. 
National Science Board (2012) Science and Engineering Indicators 2012, available at: http://www.nsf.gov/statistics/seind12/start.htm, consulted August 2012.

Ogus A (1995) Rethinking Self-Regulation. Oxford Journal of Legal Studies 15, 97-108.

Porter T, Ronit K (2006) Self-Regulation as Policy Process: The Multiple and CrissCrossing Stages of Private Rule-Making. Policy Sciences 39, 41-72.

Rothmayr C (2003) Regulatory Approaches to Biomedicine: the impact of self-regulation on the public policies for Assisted Reproductive Technology. In: Serdült U, Widmer T (eds) Politik im Fokus, Festschrift für Ulrich Klöti, pp. 425-445. NZZ Verlag, Zürich.

Rothmayr C (2006) Explaining Restrictive ART Policies in Switzerland and Germany: Similar Processes - Similar Results? German Policy Studies 3, 595-647.

Rothmayr, C, Ramjoué C (2004) Germany: ART Policy as Embryo Protection. In: Bleiklie I, Goggin ML, Rothmayr C (eds) Comparative Biomedical Policy: Governing assisted reproductive technologies, pp. 174-190. Routledge, London.

Rothmayr C, Varone F, Serdült U, Timmermans A, Bleiklie I (2004) Comparing Policy Design across Countries: What accounts for variation in ART policy?", . In: Bleiklie I, Goggin M, Rothmayr CR (eds) Comparative Biomedical Policy: Governing Assisted Reproductive Technologies, London: Routledge: 228-253, pp. 228-253. Routledge, London.

Salter B, Frewer L (2002) Public attitudes, scientific advice and the politics of regulatory policy: the case of BSE. Science and Public Policy 29, 137-145.

Schattschneider EE (1975) The Semisovereign People: A Realist's View of Democracy in America. Harcourt Brace, New York.

Schön DA, Rein M (1994) Frame Reflection. Toward the Resolution of Intractable Policy Controversies. Basic Books, New York.

Scott C (2000) Accountability in the Regulatory State. J Law \& Society 27, 38-60.

Stabile B (2006) National Determinants of Cloning Policy. Social Science Quarterly 87, 449-458.

Tiberghien Y (2009) Competitive Governance and the Quest for Legitimacy in the EU: the Battle over the Regulation of GMOs since the mid-1990s. Journal of European Integration 31, 389-407.

Töller AE (2011) Voluntary approaches to regulation - patterns, causes and effects. In: Levi-Faur D (ed) The Handbook on the Politics of Regulation, pp. 497-510. Edward Elgar Publishing, Cheltham.

Van Der Heijden J (2011) Friends, Enemies, or Strangers? On Relationships between Public and Private Sector Service Providers in Hybrid Forms of Governance. Law \& Policy 33, 367-390.

Vibert F (2007) The Rise of the Unelected: Democracy and the New Separation of Powers. Cambridge University Press, Cambridge. 
Weimer DL (2006) The Puzzle of Private Rulemaking: Expertise, Flexibility, and Blame Avoidance in U.S. Regulation. Public Administration Review 66, 569-582.

Weimer DL (2010) Stakeholder governance of organ transplantation: A desirable model for inducing evidence-based medicine? Regulation \& Governance 4, 281-302.

${ }^{1}$ Acknowledgment: to be added.

${ }^{2}$ See National Science Board, Science and Engineering Indicators 2012, Chapter 4 and 5: http://www.nsf.gov/statistics/seind12/start.htm, consulted August 2012.

${ }^{3} 2008$ Assisted Reproductive Technology Success Rates. National Summary and Fertility clinic Report. American Society for Reproductive Medicine, December 2010.

${ }^{4}$ Embryonic stem cells are capable of self-renewal and differentiation into various types of cells. For the time being, the derivation of embryonic stem cells implies the destruction of the embryo. On the contrary to reproductive cloning which aims at cloning a human being, therapeutic cloning aims at reproducing a specific type of cell by transferring an adult cell into an ovocyte. Therapeutic cloning implies the genetic modification of the ovocyte.

${ }^{5}$ In 2005, the UK government has established a ten-year funding scheme for stem cell research with the goal of making "the UK the most scientifically and commercially productive location for this activity over the coming decades, and which commands the support of public and private research funders, practitioners and commercial partners" (Press release of the 10-year vision statement). The competition has also recently increased among US states. New York State has, for instance, invested \$35 millions in stem cell research in 2010 while California has passed in 2004 a funding of $\$ 300$ millions per year over 10 years. As part of the seventh framework program, the EU heavily invests into stem cell research networks (see for a list of financed projects: http://cordis.europa.eu/fetch?CALLER=FP7_PROJ_EN\&QZ_WEBSRCH=stem+cell\&QM_PJA=\&USR_S ORT=EN_QVD+CHAR+DESC, consulted on May, $17^{\text {th }} 2013$.

${ }^{6}$ For an analysis of the vote on the issue at the 57th session of the U.N. General Assembly see Stabile 2006.

${ }^{7}$ Article 18 of the Convention bans the creation of human embryos for research purpose. In 1998, an additional protocol that bans reproductive cloning was introduced. So far, even less countries have ratified the protocol the Convention.

${ }^{8}$ In 2000, the European Parliament adopted a non-binding resolution that called for human cloning prohibition.

${ }^{9}$ CECOS (1981). Considérations éthiques sur les méthodes de procréation médicalement assistée.

${ }^{10}$ Le Monde, «Le capharnaüm de la fécondation artificielle », 3 janvier 1990, p. 15.

${ }^{11}$ Government switched from left to right to right for both 1994 and 2004 laws in the middle of the legislative process. The switch did not result into any significant change in the type of the regulatory regime.

12 The Voluntary Licensing Authority for Human in Vitro Fertilization and Embryology.

${ }^{13}$ In 2010, the German Federal Court decided that the use of PGD to prevent the transmission of grave hereditary diseases is not a criminal offence, opening the door for further political debate and policy changes.

${ }^{14}$ The German Medical Association has adapted their code to the latest developments on three occasions, for the last time in 2006 . 